УДК 343.611.1

Научная статья

DOI 10.18101/2658-4409-2020-3-16-23

\title{
ОТВЕТСТВЕННОСТЬ МЕДИЦИНСКОГО РАБОТНИКА: ПРОБЛЕМЫ ТЕОРИИ И СУДЕБНОЙ ПРАКТИКИ
}

\author{
(c) Бураева Светлана Кимовна \\ кандидат юридических наук, доцент, \\ Бурятский государственный университет имени Доржи Банзарова \\ Россия, 670000, г.Улан-Удэ, ул. Смолина, 24а \\ buradv@mail.ru
}

\begin{abstract}
Аннотация. В представленной статье рассмотрены некоторые важные аспекты и проблемные вопросы теории и судебной практики, связанные с оказанием медицинской помощи. В работе даны краткие определения таким понятиям, как врачебная ошибка, ятрогения, ятрогенная преступность, причинно-следственная связь. Рассмотрены проблемные вопросы оснований уголовной ответственности медицинского работника за неисполнение или ненадлежащее исполнение своих профессиональных обязанностей, проблемы квалификации действий (бездействия) медицинских работников, значение заключения экспертов по таким делам. Отмечаются трудности в установлении причинной связи между деянием медицинского работника и наступившими преступными последствиями в виде причинения вреда здоровью пациента либо его смерти. Кроме того, дан краткий анализ законодательным инициативам о внесении в уголовное законодательство Российской Федерации специальных норм об уголовной ответственности медицинских работников.

Ключевые слова: ошибка врача; ответственность медицинского работника; причинноследственная связь; заключение эксперта.
\end{abstract}

\section{Для цитирования}

Бураева С. К. Ответственность медицинского работника: проблемы теории и судебной практики // Вестник Бурятского государственного университета. Юриспруденция. 2020. Вып. 3. С. 16-23.

Смерть пациента в больнице всегда становилась предметом служебных проверок, целью которых является установление соблюдения алгоритма оказанной медицинской помощи больному. В судебно-следственной практике такие заключения служебной проверки являются и основанием для возбуждения уголовного дела и, конечно, доказательством причастности врача к смерти пациента. Однако известны и другие случаи, когда служебной проверкой установлено отсутствие нарушения стандартов оказания медицинской помощи. Но несмотря на такое заключение специалистов, органы следствия находят достаточные основания для возбуждения уголовного дела.

Всегда найдутся граждане, убежденные в том, что их близкий человек скончался от неправильного лечения, неправильно (несвоевременно) поставленного диагноза, а потому они убеждены, что врач либо лечебное заведение должны компенсировать им моральные страдания.

Известно о создании временной межведомственной рабочей группы по вопросам подготовки предложений о внесении в Уголовный кодекс Российской 
Федерации изменений, касающихся установления специальных норм ответственности медицинских работников за преступления по службе. Цель деятельности этой рабочей группы - совершенствование правоприменительной практики, которая позволит, с одной стороны, добиться исключения случаев необоснованного привлечения врачей к уголовной ответственности, с другой - более эффективно защищать права пациентов от возможных неквалифицированных действий медицинских работников.

Волна обвинений в адрес медицинских работников (учреждений) породила и новое понятие - ятрогенная преступность, под которой понимается разновидность преступлений против жизни и здоровья человека. Это медико-правовой термин, включающий деяния медицинского работника, повлекшие смерть пациента либо причинившие вред его здоровью.

Президент Союза национальной медицинской палаты Леонид Рошаль отмечает, что в результате совместной работы удалось исключить из риторики Следственного комитета применение к медицинским делам термина «ятрогенные преступления». «Мы договорились, и это важно, что так называемые «врачебные ошибки» не имеют отношения к понятию «ятрогения» ${ }^{1}$.

Ятрогения (от древнегреческого iatros - врач и genes - порождающий) болезнь, спровоцированная врачом. Это понятие впервые упомянуто немецким психиатром О. Бумке еще в 1925 г. в работе «Врач как причина душевных расстройств». В МКБ-10 (Международная классификация болезней), например, ятрогения трактуется более широко, как любая ошибка врача, которая повлекла за собой нарушения функций организма, инвалидность или смерть пациента. Однако ятрогения по-прежнему чаще трактуется более узко, как заболевание, негативно воздействующее именно на психику больного.

В широком смысле рассматриваемые нами случаи называют врачебной ошибкой. Существуют разные определения судебной ошибки. Как известно, законодательного определения такой ошибки не существует. Например, согласно определению И. В. Давыдовского, врачебная ошибка - это добросовестное заблуждение врача, исключающее уголовную ответственность [1, с. 84].

Действительно, в медицинском сообществе придерживаются концепции «об уголовной ненаказуемости врачебной ошибки» по причине добросовестности заблуждения врача. Но такая концепция противоречит уголовно-правовой науке.

Нет в мире государства, где бы отсутствовали врачебные ошибки. В медицинской практике имеет место фактор случайности, который трудно прогнозировать и который может обусловить непредсказуемые последствия. Проблему о врачебных ошибках нельзя сводить только к вопросам диагностики и лечения. В случае привлечения врача к уголовной ответственности возникают проблемы установления вины и причинно-следственной связи между действиями (бездействием) врача и причинением вреда пациенту. Доказать, что именно халатность врача стала причиной нанесенного ущерба - очень трудоемкая задача.

А ведь согласно ст. 8 УК РФ, единственным основанием уголовной ответственности является совершение деяния, содержащего все признаки состава преступления, предусмотренного уголовным законом.

\footnotetext{
${ }^{1}$ Пилюля. 2019. № 7. С. 26.
} 
В Уголовном кодексе РФ содержится норма, в соответствии с которой чаще всего в судебной практике квалифицируются действия врача, допустившего либо смерть пациента, либо причинение тяжкого вреда его здоровью.

Так, согласно ч. 2 ст. 109 УК РФ, уголовная ответственность предусмотрена за причинение смерти по неосторожности вследствие ненадлежащего исполнения лицом своих профессиональных обязанностей.

По статистике Следственного комитета РФ, в 2018 г. до суда дошло 300 уголовных дел о так называемых врачебных ошибках. Всего же в Следственный комитет поступило 6500 жалоб на действия медиков, а возбуждено было 2029 уголовных дел ${ }^{1}$.

Допускаем, что даже при установлении, например, в ходе служебной проверки факта оказания неквалифицированной медицинской помощи не всегда этот факт является причиной смерти пациента либо причинения тяжкого вреда его здоровью.

По нашему мнению, вопрос о причинно-следственной связи оказанной (не оказанной) медицинской помощи и наступлением последствий в виде смерти пациента либо причинения вреда его здоровью является краеугольным в установлении вины медицинского работника.

Непременным условием уголовной ответственности является наличие причинной связи между действием (бездействием) и наступившими общественно опасными последствиями.

Причинная связь представляет собой объективно существующую связь между общественно опасным деянием и наступившими преступными последствиями.

Суть этих отношений проявляется во взаимодействии между явлениями, при котором одно или несколько из них (действие или бездействие) порождает другое (преступное последствие). В теории уголовного права и практике применения уголовного закона господствует положение, согласно которому за объективно случайные последствия своих действий лицо не может нести уголовную ответственность, поэтому при отсутствии причинной связи уголовная ответственность за наступление таких последствий исключается [2, с.189-190].

Квинтэссенция теории эквивалентной причинности заключается в том, что причиной преступных последствий признается любое действие (бездействие), которое выступало необходимым условием наступления преступного результата.

Чаще всего деяние и наступившие последствия настолько связаны друг с другом, что установление причинной связи между ними не вызывает трудностей (например, при выстреле в упор, когда смерть человека наступает мгновенно). Но судебной практике известны случаи, когда между деянием и наступившими последствиями могут быть разрывы во времени, в связи с чем отсутствует очевидность того, что эти последствия стали результатом деяния, т. е. находятся с ним в причинной связи. Такие обстоятельства как раз и выявляются по делам о так называемых врачебных ошибках.

Предпосылкой возникновения вопроса о причинной связи прежде всего является достоверное установление не только определенного вредного последствия, но и факта совершения лицом, которому вменяется это последствие, общественно опасного деяния, содержащего признаки конкретного состава преступления.

\footnotetext{
${ }^{1}$ Российская газета. Федер. вып. № 89(7847).
} 
Особое значение данное требование имеет в случаях, когда состав преступления предполагает невыполнение или ненадлежащее выполнение определенных правил [3, c.164].

В судебной практике встречаются уголовные дела, по которым установлен лишь факт наступления преступных последствий, например, в виде смерти пациента. При этом ставится вопрос о причинной связи даже тогда, когда врачом не были нарушены какие-либо стандарты (правила) оказания медицинской помощи. Либо нарушение этих правил не находится в причинной связи с наступлением смерти.

Сложности в судебно-следственной практике возникают тогда, когда в причинную связь вмешиваются силы, непосредственно не связанные с действиями обвиняемого, но каким-то образом влияющие на преступный результат. В такой ситуации важно отграничить из всех факторов, содействующих возникновению последствий, тот фактор, который явился определяющим в наступлении преступного результата.

Например, потерпевшему было причинено проникающее ножевое ранение. Во время операции по халатности хирурга в брюшной полости был оставлен тампон, в результате чего развился воспалительный процесс, приведший к смерти. Имеется ли причинная связь меду действиями преступника и наступлением смерти?

Но уместнее привести другой пример. В Центральной районной больнице Республики Бурятия при поступлении ребенка в стационар на Скорой помощи не был правильно поставлен диагноз. Ребенку назначено соответственно неадекватное лечение. Ночью ребенок скончался. Согласно заключению СМЭ, смерть наступила в результате ....

На этот краеугольный вопрос отвечает эксперт, поскольку вопрос о причинной связи между преступным деянием и последствием находится в его компетенции.

Определение причинно-следственных связей может не требовать специальных познаний, и тогда оно осуществляется непосредственно следователем и судом. Если же специальные познания необходимы, для установления причинности назначается экспертиза [5].

Определение причинной связи между травмой и ее последствиями входит в обязанности судебно-медицинских экспертов. В Медицинских критериях определения степени тяжести вреда, причиненного здоровью человека (приложение к Приказу Министерства здравоохранения и социального развития Российской Федерации от 24 апреля 2008 г. № 194н), наблюдается разночтение в задачах экспертам: где-то требуется оценить причинную связь, где-то прямую причинноследственную связь; причинно-следственную связь, непосредственно сопряженную с последствием. Вместе с тем нигде нет указаний на то, как именно надлежит устанавливать связь вообще и ее виды в частности.

Установление причинно-следственной связи - достаточно сложный вопрос, до настоящего времени не имеет однозначного решения, что нередко приводит к возникновению экспертных ошибок, к непониманию между юристами и судебными медиками [4].

Руководитель Следственного комитета России А. И. Бастрыкин отмечал значение экспертного заключения как одного из основных доказательств по уголовному делу. По рассматриваемой категории дел назначение судебно-медицинской экспертизы является обязательным в соответствии со ст. 196 УПК РФ. 
Могут быть обстоятельства для разумных сомнений в выводах эксперта. Например, выход за пределы своей компетенции, информация в документах, вызывающая сомнения, противоречивые или взаимоисключающие выводы и т. д. Указанные ситуации, а также ошибки в решении каких-либо вопросов, в том числе и по установлению причинно-следственных связей, должны являться основанием для назначения повторных (дополнительных) экспертиз. При этом следует руководствоваться принципом свободы оценки доказательств, в соответствии с которым никакие доказательства не имеют заранее установленной силы (ч. 2 ст. 17 УПК РФ).

Изучение экспертиз показывает отсутствие должной аргументации в выводах экспертов о видах связи. Чаще всего эксперты приводили в ответах данные без конкретных развернутых обоснованных объяснений своего решения, без доказательства закономерного развития событий.

Проблемным вопросом судебной практики остается нежелание подвергать объективной оценке заключения специалистов и мотивировать свои выводы о непризнании, например, заключения специалиста достоверным доказательством. Тогда как в соответствии с п. 3.1 ч. 2 ст. 74 УПК РФ в качестве доказательств допускаются показания и заключение специалиста (наряду с заключением эксперта).

Так, по делу Табжагиной В. П., врача станции Скорой медицинской помощи, в соответствии со ст. 53, 86 УПК РФ, ст. 6 ФЗ «Об адвокатской деятельности и адвокатуре в РФ» защитником был привлечен специалист - доктор медицинских наук, профессор, заведующий кафедрой анестезиологии и реаниматологии Иркутского института усовершенствования врачей. Его заключением опровергались выводы судебно-медицинской экспертизы, проведенной в ходе предварительного расследования, в том числе по вопросу о причине смерти ребенка.

При наличии взаимно исключающих доказательств судом не была назначена повторная экспертиза. Но в основу своих выводов о виновности врача суд положил, конечно, заключение СМЭ, полученное в ходе следствия.

В судебном решении указано: «Суд считает достоверными и обоснованными выводы комиссионной экспертизы... Мнение специалиста Горбачева, не согласного с выводами экспертов о допущенных врачом нарушениях при оказании помощи больному, суд считает лишь частным мнением врача... Заключение специалиста не является заключением эксперта, полученным в соответствии с нормами УПК... Специалист не предупреждался об ответственности в отличие от комиссии экспертов... суду не известны условия его приглашения в судебное заседание, оплаты его услуг и могло ли оно повлиять на достоверность выводов специалиста...».

Что из перечисленных доводов соответствует закону? При такой оценке доказательств невозможно рассчитывать на законное судебное решение. И появление новых статей в Уголовном законе не решит проблемы квалификации и доказывания по так называемым врачебным ошибкам.

Как известно, Следственный комитет РФ предлагает внести в УК РФ новые статьи: ст. 124.1 «Ненадлежащее оказание медицинской помощи» и ст. 124.2 «Сокрытие нарушения оказания медицинской помощи». Кроме того, предлагается изложить в новой редакции ст. 235 УК РФ «Незаконное осуществление медицинской и (или) фармацевтической деятельности». 
Ст. 124.1 предполагает уголовную ответственность за ненадлежащее оказание медицинской помощи или услуги, если это повлекло за собой смерть человека или двух и более лиц либо гибель плода и/или причинение тяжкого вреда здоровью человека. Предлагается наказание в виде штрафа до 500000 р. либо лишение свободы на срок от двух до семи лет и запрет занимать определенные должности.

Как известно, доктор Л. Рошаль считает, что за неумышленные осложнения врач не должен сидеть в тюрьме. Поэтому обсуждается вопрос об иных видах наказания для врачей, которые должны стать альтернативой лишению свободы.

Представители Национальной медицинской палаты выступили против включения в проект предлагаемой ст. 124.1 УК понятия «плод». По мнению экспертов Палаты, отнесение плода человека к предмету уголовного права приведет к массовому исходу из профессии акушеров и неонатологов.

Ст. 124.2 предполагает уголовную ответственность за внесение недостоверных сведений в медицинскую документацию, ее сокрытие либо уничтожение, а также подмену биологических материалов с целью сокрытия ненадлежащего оказания медицинской помощи другим медицинским работником, действия которого повлекли смерть, причинение тяжкого вреда здоровью либо гибель плода.

Предлагаемые новеллы в ст. 235 УК (в редакции законопроекта) направлены на установление единообразной правоприменительной практики, поскольку в настоящее время оказание медицинской помощи с использованием поддельных документов квалифицируется по различным статьям УК (например, 327 УК РФ), при этом тяжесть причиненного такими действиями вреда здоровью человека не учитывается.

Возможно, целью таких инициатив является желание выделить в уголовном законе специальные составы преступлений и ответственность за них медицинских работников.

Кроме того, усилия Медицинской палаты направлены на то, чтобы в отношении врачей не применялась ст. 238 УК РФ, предусматривающая ответственность за оказание услуг, не отвечающих требованиям безопасности ${ }^{1}$.

Предлагаемые изменения в отличие от действующих норм УК РФ содержат указание на специальный субъект преступления - медицинского работника, конкретизируют вид помощи - медицинской, в том числе медицинских услуг, учитывают различные последствия. В связи с этим такая норма будет являться специальной по отношению к вышеуказанным общим нормам уголовного закона, согласно правилам квалификации, при конкуренции общей и специальной норм будет применяться специальная. Данные новеллы, по мнению Следственного комитета, позволят минимизировать ошибки правоприменения.

Но ведь врачебные ошибки могут заключаться не только в указанных действиях (бездействии), но и, например, в распространении информации, относящейся к врачебной тайне и персональным данным, в подмене детей в родильном доме. Последнее, как правило, выявляется спустя годы. Кого привлекать к ответственности?

Судебная практика РФ по рассмотрению исков о взыскании компенсации за причиненный моральный вред при таких обстоятельствах неоднозначна. Это тоже,

\footnotetext{
${ }^{1}$ Пилюля. 2019. № 7. С. 26.
} 
на наш взгляд, является проблемой правоприменительной практики Российской Федерации.

Так, в Республике Бурятия в 1983 г. в Курумканской ЦРБ у разных рожениц родились девочки. При выписке девочки были переданы не своим родителям. Подмена была установлена в 2016 г. Одна из матерей предъявила иск к Курумканской ЦРБ, Министерству здравоохранения РБ о взыскании компенсации морального вреда.

Решением Советского районного суда г. Улан-Удэ от 15 января 2019 г. в иске отказано вследствие того, что на момент причинения вреда при выписке истца с новорожденным ребенком в январе 1983 г. действовавшими законодательными актами СССР и РСФСР такой вид ответственности, как взыскание компенсации морального вреда, не был установлен. Все последующие судебные инстанции Республики Бурятия подтвердили это решение.

Вместе с тем в разных регионах РФ принимаются иные решения по аналогичным искам. Например, решением Центрального районного суда г. Челябинска частично удовлетворены исковые требования истцов о взыскании компенсации за причиненный моральный вред в размере 1 млн р. При этом суд указал в решении следующее. Если противоправные действия ответчика, причиняющие истцу нравственные или физические страдания, начались до вступления в силу закона, устанавливающего ответственность за причинение морального вреда, и продолжаются после введения этого закона в действие, то моральный вред подлежит компенсации.

Определением Ленинградского областного суда оставлено без изменений решение Волосовского районного суда Ленинградской области, которым также удовлетворены исковые требования о взыскании компенсации. А жалобы ответчиков оставлены без удовлетворения.

При этом суды, как видно из указанных решений, руководствуются разъяснениями пленума Верховного суда РФ «Некоторые вопросы применения законодательства о компенсации морального вреда» от 20.12.1994 г. № 10, где в п. 6 постановления прямо указано: «... однако, если противоправные действия (бездействие) ответчика, причиняющие истцу нравственные или физические страдания, начались до вступления в силу закона, устанавливающего ответственность за причинение морального вреда, и продолжаются после введения этого закона в действие, то моральный вред в указанном случае подлежит компенсации» ${ }^{1}$

Во всех случаях, по нашему убеждению, моральные страдания истцов по вине ответчиков в результате подмены детей продолжались и на момент подачи исков. Противоправное деяние ответчиков и его последствия, таким образом, продолжаются и ответчиками не устранены. Однако судебная практика, как видно, не является единообразной.

\section{Литература}

1. Бобринская И. Г., Григорьев Ю. Г., Гутова Е. В. Проблема: врачебные ошибки - ошибки врача // Вестник интенсивной терапии. 2012. № 1. С. 84.

\footnotetext{
${ }^{1}$ Некоторые вопросы применения законодательства о компенсации морального вреда: постановление пленума Верховного суда РФ от 20 декабря 1994 г. № 10.
} 
2. Уголовное право России. Общая часть: учебник / под ред. И. Э. Звечаровского. М., 2010. С.189-190.

3. Советское уголовное право. Общая часть / под ред. Г. А. Кригера, Б. А. Куринова, Ю. М.Ткачевского. М., 1981. С. 164.

4. Проблема причинно-следственных отношений в практической судебной медицине / А. А. Солохин [и др.]. // Суд.-мед. эксперт. 1984. № 1. С. 15.

\section{LIABILITY OF MEDICAL STAFF: ISSUES OF THEORY AND COURT PRACTICE}

Svetlana K. Buraeva

Cand. Sci. (Law), Senior Lecturer,

Dorzhi Banzarov Buryat State University

24a Smolina St., Ulan-Ude 670000, Russia

burdv@mail.ru

Abstract. The article reviews a few aspects and problematic points of the theory and judicial practice, related to health services delivery. Short definitions, such as medical malpractice, iatrogenesis, and iatrogenic crime are given hereto. There were considered the following problematic issues of a medical worker liability for failure to perform or improper performance of professional duties, the problem of actions (inactions) of a medical worker qualification, the value of expert opinion in such cases. There were noted the significance and difficulties in setting up of causal connection between action of a medical worker and occurred criminal consequences. There were given a brief analysis of legislative initiatives to amend the criminal legislation of the Russian Federation with regard to special norms on criminal liability of medical workers.

Keywords: medical error; medical worker's liability; causal connection; expert's opinion.

Статья поступила в редакцию 25.09.20; одобрена после редактирования 01.11.20; принята к публикации 05.11.20. 